\title{
The Potential of Antitrust Collective Litigation
} in 2017

\section{Beyond the Recommendation and the Directive}

Žygimantas Juška

PhD candidate, Universiteit Leiden, Europa Institute, The Netherlands

z.juska@umail.leidenuniv.nl

\begin{abstract}
The European Commission expected to assess the implementation of the 2013 Recommendation on collective redress by 26 July 2017, yet the Commission missed the deadline. Despite this failure, the Recommendation is still on the EU agenda: a public consultation has been started with the intention to assess how the EU member states responded to the 2013 proposal. On the one hand, it should be welcomed that the Commission remains ambitious regarding an EU-wide collective redress mechanism. On the other hand, it should be highlighted that the Commission is concentrating too much on the American system, which significantly differs in terms of rationale, design, and stated goals. Indeed, utilising one or another American element does not inevitably lead to the perceived issue of "blackmail settlement". This is further qualified by positive experiences in pro-active EU member states, which have experimented with Us-oriented tools in order to facilitate collective actions in their jurisdictions. This article explores how insights from the EU countries and the Us should influence the debate on EU-style collective antitrust redress, if and when the time arises to take another step in the field.
\end{abstract}

\section{Keywords}

collective actions - competition law - private enforcement - damages claims compensation 
More than 4 years have passed since the European Commission adopted the reform on damages actions in June 2013. The reform sought to facilitate antitrust damages actions across the European Union. The most important milestone was reached in November 2014, when the EU adopted the Directive on antitrust damages actions. ${ }^{1}$ Its main objective was to ensure that victims could effectively exercise their right to claim full compensation. However, the achievement of full compensation is highly distorted for victims who suffered low value harm (such as consumers and purchasers). The Directive does not include provisions on collective redress; instead, the horizontal Recommendation on collective redress was adopted for this purpose. ${ }^{2}$ It is not a legally binding document, and as such cannot force member states to take action; it only urges it. However, the Recommendation still represents the latest and the most concrete EU proposal, under which the preparation of legislation has been made for a coherent European framework for collective redress. This document has two main goals. The first is to facilitate access to justice, and to enable compensation in mass harm situations. The second is to prevent the same kind of litigation abuses that have occurred in us class actions. It was planned that by 26 July 2017, the European Commission would assess the practical implementation of the Recommendation and, if necessary, propose further legislative measures. However, the Commission missed this deadline. Despite this, the Commission still seeks to fulfil its obligations from 2013. Therefore, a public consultation has been started in order to assess the implementation of the Recommendation in the member states. The results should be made public at some time in 2017. If the Commission finds that there is a need to regulate collective actions at the EU level, consumers may expect a new policy instrument in the following years.

Regardless of what the results of the consultation will be, the truth is that the Recommendation has had little real impact on the development of collective actions in the $\mathrm{EU}$ and that these actions are getting more and more divergent across the member states. An even more important factor that antitrust mass claims have been brought in states which disregard the proposed

1 Directive 2014/104/EU of the European Parliament and of the Council of 26 November 2014 on certain rules governing actions for damages under national law for infringements of the competition law provisions of the Member States and of the European Union [2014] OJ L349.

2 Commission Recommendation of 11 June 2013 on common principles for collective redress mechanisms in the Member States for injunctions against and claims on damages caused by violations of EU rights $\operatorname{COM}(2013) 3539 / 3$. 
principles of the Commission, and instead allow for Us-oriented tools in some fashion. In light of these observations, this paper will provide an overview of the proposed EU approach and suggest possible amendments to the expected legislative measures in the near future.

The structure of this paper is as follows. The next section provides an overview of the development of collective redress, ranging from the 2005 Green Paper to the 2013 Recommendation. The study of the Commission's proposed approach is outlined in section three. The last section gives an overview of the schemes of member states that disregard some conservative principles of the EU approach in order to achieve success in collective litigation.

\section{An Overview of the Commission's Recommendation on Collective Redress}

The Commission's efforts to introduce an EU-wide private antitrust enforcement may be traced back to the 2005 Green Paper on damages actions. ${ }^{3}$ The main objective was to identify barriers to the further promotion of antitrust damage actions. ${ }^{4}$ Furthermore, collective redress actions were proposed as a tool for protecting consumers and purchasers with small claims. Despite the Commission proposing a number of options to facilitate damages claims, the efforts were highly criticised. ${ }^{5}$ Building on these initial efforts, the Commission published the 2008 White Paper on damages actions. ${ }^{6}$ In order to stimulate damage claims, the document included a broad range of suggestions: (1) the availability of full compensation (actual loss plus and the loss of profit); (2) the judge-controlled disclosure; (3) binding effect on NCA's decisions;

3 European Commission, "Green Paper-Damages actions for breach of the EC antitrust rules", сом (2005) 672 final.

4 At this point, the Commission identified 6 main obstacles to creating a more effective system of antitrust damages actions. They relate to the following areas: (i) access to evidence (ii) damages (iii) defending consumer interests (iv) effect of damages claims on the leniency programme (v) defending consumer interests (possibility of collective actions) (vi) The passing-on defence and indirect purchaser's standing.

5 See, e.g. Editorial comments, "A little more action please! — The White Paper on Damages Actions for Breach of the EC Antitrust Rules" Common Market Law Review 45(3) (2008) 6o9-615; Office of Fair Trading, “Response to the European Commission's Green Paper, Damages Actions for Breach of the EC Antitrust Rules" (2006), available at <http://ec.europa.eu/competition/antitrust/actionsdamages/files_green_paper_comments/office_of_fair_trading.pdf $>$.

6 European Commission, "White Paper on Damages actions for breach of the EC antitrust rules", сом (2008) 165 . 
(4) single damages rather than multiple damages. In addition, the White Paper recognised a clear need for collective redress mechanisms, as the existing means for the aggregation of individual claims were often limited and the harm caused by competition infringement was typically scattered amongst a large number of injured parties. ${ }^{7}$ As a result, two types of collective actions were suggested: (i) representative actions; and (ii) opt-in collective actions.

In both papers, the European Commission failed to find a consensus for an EU-wide legislation on antitrust collective redress. This is mainly because member states were against a sector-specific measure in the field. However, these failures incentivised the Commission to carry out a public consultation in February 2011. ${ }^{8}$ This time the proposal supported a horizontal approach, which allows for all types of collective redress actions. In particular, it set out the core principles for a coherent European horizontal framework for collective redress in the subsequent Recommendation on collective redress. ${ }^{9}$ The main principles that the Commission expects the member states to abide by are the following: ${ }^{10}$

- Depending on the type of claim, collective redress can take two forms: injunctive relief (claims seeking to stop unlawful practice) and compensatory actions (claims seeking compensation for damage suffered).

- An opt-in principle should be the only approach to aggregate victims in collective redress claims. Under this model, the group includes victims who express consent to join the action.

- A clear distinction is made between public enforcement and compensatory damages actions: both instruments remain institutionally independent of each other. Public enforcement focuses on the punitive objective-function. This function is pursued through the imposition of fines. Compensatory collective redress actions should serve the objective of full compensation, i.e. the compensation model that sets the background for the Directive on

$7 \quad$ Ibid., sec 2.1 .

8 European Commission, "Public Consultation: Towards a Coherent European Approach to Collective Redress", SEC (2011) 173 final.

9 Together with the Recommendation, it was issued the Communication from the Commission to the European Parliament, the Council, the European Economic and Social Committee and the Committee of the Regions "Towards a European Horizontal Framework for Collective Redress", сом(2013) 401/2.

10 The following discussion is based on the Recommendation, op.cit note 2; Communication op.cit note 9 . 
damages actions. ${ }^{11}$ Therefore, punitive damages, multiple or other damages, which lead to overcompensation, should be prohibited in a European collective redress mechanism.

- The Recommendation allows for both group actions and representative actions. The provisions on group actions are not widely discussed in the Recommendation. It can be argued that the Commission's main objective is to facilitate representative actions. This representation model better achieves the interests of victims, because public authorities are bound by their organisational mission to represent them in their best interests. Accordingly, legal standing can only be granted to entities designated in advance or by entities which have been certified on an ad hoc basis.

- Member States should not permit contingency fees, as this risks creating an incentive to conduct abusive litigation. The Commission establishes strict safeguards on third party funding. The funders are to be scrutinised in order to guarantee that there are no conflicts of interest, and that they have sufficient funds to support the legal action. Finally, the 'loser pays' principle should be predominant for reimbursing legal costs to winners.

The principles outlined in the Recommendation are non-binding, and hence, states are only encouraged to follow them. In June 2013, it was decided that the implementation of the Recommendation will be assessed by 26 July 2017, and further legislative measures will be proposed, if found necessary. However, the Commission has failed in assessing the practical implementation of the Recommendation in time. Despite this failure, the Recommendation is still on the EU agenda: the Commission has started a consultation on the functioning of collective redress schemes in the EU member states. The Commission should provide a report during 2017. For the potential stakeholders, the most important thing is that the European Commission has not changed its policy since 2013. Therefore, the measures proposed in the 2013 Recommendation are still considered the most appropriate for the EU policy on collective redress.

11 According to article 1 of the Directive, op.cit note 1, anyone who has suffered harm by antitrust infringement can effectively exercise the right to claim full compensation. The Directive reaffirms the EU acquis communautaire: White Paper, op.cit note 6 and the judgements of the Court of Justice of the European Union in Case C-453/99 Courage Ltd. v. Bernard Crehan [2001] ECR I-6297 and Joined Cases C-295/04 to 298/04 Vincenzo Manfredi and Others $v$ Lloyd Adriatico Assicurazioni SpA and Others [2006] ECR I-6619. 
Although the Recommendation is not legally binding, it is the most concrete EU policy measure in the area of collective redress. The Recommendation represents the $\mathrm{EU}$ position, according to which an indirect action has been made for the preparation of legislation for a coherent European framework for collective redress. Logically, it should share the best practices that would incentivise member states to reconsider the available collective redress schemes, or to incentivise their development in states that have not yet adopted them. However, the implementation of the Recommendation has failed, because member states have introduced collective redress schemes in their own fashion. Even if it may sound paradoxical, this failure should be welcomed. This is notable because the Commission's proposed measures/safeguards are too robust for collective actions (especially in antitrust) to ever be brought to the courts. In fact, the strong safeguard mechanism is rather a reflection of the Eu's conservative approach, which seeks to avoid any relationship with the American system. However, the experiences in the EU member states have shown that antitrust collective actions have been brought in countries that disregard conservative EU measures and instead experiment with Us-oriented tools. All these points will be discussed below.

\subsection{The Surrounding Controversies}

The stated goal of the Recommendation is to provide better means of access to justice, and to enable compensation in mass harm situations. In order to achieve this goal, the Recommendation combines tools that are based on the conservative approach. First, there is a predominance of the 'loser-pays' principle and an opt-in measure. Second, the E $\mathrm{U}$ model prohibits contingency fees and punitive damages - also, third party funding is subject to strict limitations. Third, the representative entities need to meet strict requirements for bringing representative actions: a non-profit making character, a direct relationship between the activities of entity and the violation, and sufficient capacity in terms of financial and human resources. ${ }^{12}$ Together, these tools act as robust safeguards against abusive litigation. However, these safeguards simultaneously reduce the incentives of bringing compensatory collective actions to a minimum. ${ }^{13}$ In essence, a defeat in a case would entail having to compensate the other side's costs, which may be significant. Moreover, opt-in schemes are

\footnotetext{
12 Recommendation, op.cit note 2, para. 4.

13 Some commentators argue that the EU policy on collective redress faces the 'Catch 22' problem, under which safeguards are in fact working as barriers. See C. Hodges,
} 
accused of attracting a too low participation rate, which absolutely diminishes the financial viability of collective actions. ${ }^{14}$ Finally, the prohibition of contingency fees lessens the possibilities of reaping awards outweighing the risks of litigation. Under these conditions, few rational actors would be willing or capable of bringing costly antitrust collective actions. As such, the objective of compensating victims in mass harm situations is likely to fail to a large extent, as collective actions are unlikely to be brought. As such, a large majority of victims will remain uncompensated.

Another concern is that the Recommendation fails to lay down clear requirements on how the EU policy should be formed. The proposed principles are poorly defined, and create legal uncertainty by including many exemptions. ${ }^{15}$ Table 1 below explains these exemptions:

The issue is that the Commission urges member states to implement the proposed principles, yet there is a lot of space for interpretations. But the European Commission has already observed that a lack of clarity in the soft law may lead to further fragmentation in the national systems. ${ }^{16}$ As a proof of this, it can be observed that the development of collective redress mechanisms has resulted in a number of uncoordinated initiatives during 2013-2016. Collective redress schemes were introduced in Lithuania in 2015, with the possibility for attorneys to sign a contingency fee agreement. ${ }^{17}$ The UK amended its Consumer Rights Act in 2015, thereby allowing opt-out antitrust collective proceedings. ${ }^{18}$ To the same extent, opt-out actions are allowed in Belgium from 2014,

"Collective Redress: A Breakthrough or a Damp Sqibb?" Journal of Consumer Policy 37(1) (2014), 67-89, at 83 .

14 For the discussion on low participation rates, see R. Van den Bergh, "Private Enforcement of European Competition Law and the Persisting Collective Action Problem" Maastricht Journal 20(1) (2013), 12-34, at 21. For the discussion on the financial viability, see Which?, 'Response to European Commission Consultation on Collective Redress' (2011), availableat<http://ec.europa.eu/competition/consultations/2011_collective_redress/ which_en.pdf $>$.

15 For a discussion, see also Hodges, op.cit note 13, at 78.

16 Commission Staff Working Document accompanying document to the White paper on damages actions for breach of the EC antitrust rules-Impact assessment, SEC (2008) 405, para. 147 .

17 In order to allow group actions, the Code of Civil Procedure was amended by introducing article $441^{1}$. Also article $49(6)$ of the Code was withdrawn. Contingency fees are allowed under article 50 of the Law on Advocacy.

18 Major amendment is set out in Schedule 8, entitled "Private Actions in Competition Law." See Consumer Rights Act 2015, available at <http://www.legislation.gov.uk/ukpga/2015/15/ contents/enacted>. 


\begin{tabular}{|c|c|c|}
\hline Measure & The commission's aspiration & Exemption \\
\hline Opt-in & $\begin{array}{l}\text { Each collective redress action } \\
\text { should be based on an opt-in } \\
\text { measure. }\end{array}$ & $\begin{array}{l}\text { An opt-out measure may be } \\
\text { duly "justified by reasons } \\
\text { of sound administration of } \\
\text { justice." }\end{array}$ \\
\hline $\begin{array}{l}\text { "Loser pays" } \\
\text { principle }\end{array}$ & $\begin{array}{l}\text { The losing party should } \\
\text { reimburse the other side's } \\
\text { legal costs }\end{array}$ & $\begin{array}{l}\text { The "loser pays" principle } \\
\text { should be subject to national } \\
\text { legal provisions. }\end{array}$ \\
\hline Contingency fees & $\begin{array}{l}\text { Member states should not } \\
\text { permit contingency fees in } \\
\text { collective actions }\end{array}$ & $\begin{array}{l}\text { Such fees may be allowed } \\
\text { if they are regulated by } \\
\text { national law. }\end{array}$ \\
\hline $\begin{array}{l}\text { Private third-party } \\
\text { funding }\end{array}$ & $\begin{array}{l}\text { It is prohibited to base funders' } \\
\text { compensation on the amount } \\
\text { of the settlement, or on the } \\
\text { compensation granted. }\end{array}$ & $\begin{array}{l}\text { Funding agreement can } \\
\text { be regulated by a public } \\
\text { authority. }\end{array}$ \\
\hline The court's role & $\begin{array}{l}\text { A judge should manage the } \\
\text { case effectively and detect } \\
\text { abuses as early as possible. }\end{array}$ & $\begin{array}{l}\text { The judge should carry out the } \\
\text { necessary examination by his } \\
\text { or her own initiative. }\end{array}$ \\
\hline
\end{tabular}

yet this possibility is only available to Belgian residents. ${ }^{19}$ In 2014, opt-in collective actions were introduced in France, but some procedural measures do not fit in the Eu context. ${ }^{20}$ Finally, none of the countries that allow for opt-out collective actions in some fashion (Denmark, Portugal, and the Netherlands) have changed their schemes into opt-in actions.

Indeed, the discrepancies between the legal systems create an uneven playing field in the internal market as regards antitrust damages. As a result,

19 Act of 28 March 2014, Official Gazette on 29 April 2014, 35201.

20 Class action proceedings were introduced by Law No. 2014-344 of 17 March 2014. Consumer actions are governed by Consumer Code, arts 423-1. One of the exceptional measure is that collective actions are only possible when the court asserts the defendant's liability. Another is that the Court needs to rule on the admissibility of the action and on the defendant's liability in the same court decision. For further discussion, see C. Gateau and A. Diallo, "How Does the New French Class Actions Law fit in the EU Framework?" (2014) Hogan Lovells, available at <http://www.lexology.com/library/detail.aspx? $\mathrm{g}=5 \mathrm{~d} 6 \mathrm{od}$ 9ff-261a-49fc-975c-363e1124c8oe $>$. 
undertakings that have violated articles 101 and 102 of the TFEU are facing different levels of risk of being exposed to private claims from all potential antitrust victims, including the ones with smaller claims (typically consumers and small businesses). Indeed, the infringers can be exposed to such a wideranging collective actions only if they are established in a claimant-friendly state, which allows for aggregating claims on the basis of an opt-out. It consequently leads to a so-called "competitive advantage" for undertakings that have breached competition rules. ${ }^{21}$ In that regard, the opportunity for victims to claim compensation depends on whether they are located in a state with favourable rules on collective litigation.

Another issue is that an uneven playing field encourages "forum shopping"plaintiffs choose the most favourable forum for bringing their claims. Indeed, "forum shopping" should be understood both from the negative and positive sides. As regards the negative perspective, victims with smaller claims lack the financial resources to choose a more favourable jurisdiction. ${ }^{22}$ Therefore, the European Commission considers that "forum shopping is a privilege for the happy few."23 The possibility for defendants to select the most favourable forum for defending their claims can be considered as both a positive and negative. On the one hand, "forum shopping" may bring uncertainties for national courts on whether they have jurisdiction. In addition, it may lead to a flood of claims (including the claims that lack ground) to states with favourable rules, such as the Netherlands. ${ }^{24}$ On the other hand, it allows for defendants to choose a country that may solve the proceedings in the most efficient way, also allowing to save litigation costs. As such, the extended right to bring damages claims is likely to ensure that more meritorious actions will reach the courts. Another viewpoint is that $\mathrm{EU}$ member states with effective collective redress schemes may encourage other states with underdeveloped laws to amend their systems in order to facilitate litigation opportunities in their respective

21 Commission, Proposal for a Directive of the European Parliament and of the Council on certain rules governing actions for damages under national law for infringements of the competition law provisions of the Member States and of the European Union, сом(2013) 404 final, pp. 9-10.

22 Commission, Proposal for a Directive of the European Parliament and of the Council on certain rules governing actions for damages under national law for infringements of the competition law provisions of the Member States and of the European Union, Сом(2013) 404 final, pp. 9-10.

23 J.Almunia, "Antitrust damages in Eu law and policy" College of Europe G CLC annual conference (2013), available at <http://europa.eu/rapid/press-release_SPEECH-13-887_en.htm>.

24 S. Beeston and A. Rutten, "The Dutch torpedo case" Competition Law Insight (2015) 14-15, at 14 . 
forums. Nonetheless, no one can ensure that the competition between national systems and their various litigation landscapes will not make the playing field even more uneven.

Indeed, the divergence across the $\mathrm{EU}$ makes the possible introduction of a coherent European framework for collective redress highly complicated. A legally binding measure would require intervention in national laws which already have specific schemes in place. Obviously, it would be very complicated to define a balance between the different mechanisms of member states. But if the Commission decided to adopt a legally binding instrument, it would be advisable to adopt a sector-specific antitrust Directive on collective redress rather than issue a horizontal instrument. Under a sectorial measure, minimum standards could be set that would prevent harsh intervention in national laws. ${ }^{25}$ Moreover, it would allow better adjustment to the unique nature of antitrust litigation, which requires compensating victims through different distribution chains. However, the provisions in the Directive should be set with extreme precision, because even a small lack of clarity may lead to uneven implementation. As the EU practice has shown, this issue may even occur due to the ordinary development of competition. ${ }^{26}$

If the EU truly seeks to achieve success in compensating victims in mass harm situations, there is a need to reconsider its strict approach to the American system. The introduction of one or more us elements would not necessarily lead to abusive litigation. On the contrary, there are arguments that some American elements may have positive effects in safeguarding against abuse.

\subsection{A Relationship with us Class Actions}

Throughout history, US antitrust class actions have become one of the most, if not the most important tool for enforcing antitrust rules. Yet, this is mainly because the American system combines remedies that are aimed at achieving deterrence: an opt-out measure, contingency fees, treble damages, the oneway fee shifting (the absence of the 'loser-pays' principle) and wide-ranging discovery rules. But the American system is considered to create incentives for

25 Consolidated Version of the Treaty on European Union [2008] oJ C115/13, Article 288. A directive shall be binding, but shall leave to the national authorities the choice of form and methods. Therefore, a directive shall set minimum standards that would allow for member states to introduce more stringent measures.

26 See, e.g. Directive 2009/12/EC of the European Parliament and of the Council of 11 March 2009 on airport charges [2009] OJ L 70. For further discussion, see European Commission, "Aviation: Commission reports increased transparency in setting of airport charges, but uneven implementation of rules by the Member States" Press Release of 19 May 2014, available at $<$ http://europa.eu/rapid/press-release_IP-14-567_en.htm>. 
abusive litigation. This phenomenon mainly occurs if unmeritorious collective actions are brought to the courts, and if these actions force law-abiding defendants (especially businesses) to settle in order to avoid reputational and financial damage. ${ }^{27}$ In the us context, this issue is called a "blackmail settlement."28 In order to prevent the perceived American problem, the European Commission warns against four tools:

- An opt-out system, which may jeopardize the freedom of claimants to decide whether they want to litigate or not.

- Third-party funding, which are seen as a potential factor driving frivolous actions.

- Contingency fees, which may create a risk for incentives to abuse the litigation.

- Punitive damages, which may lead to overcompensation of claimants.

However, the Commission's approach is one-sided: these measures are shown only from the negative perspective, while positive aspects are ignored.

With regard to an opt-out approach, the counterclaim to the Commission's position is the Court of Justice of the European Union's decision in Eschig. ${ }^{29}$ The Court ruled that opt-out actions are potentially in line with legal traditions as long as victims can effortlessly opt-out. Therefore, the claimant's freedom to litigate or not to litigate can be respected even in opt-out actions.

Moreover, it should be stressed that contingency fees and third party funding may have positive effects in facilitating meritorious litigation when they are combined with the 'loser pays' rule. A lawyer or a funder (hereafter both regarded as "investors") bringing unmeritorious claims should assume the risk of being hit with the other side's costs, if the case is lost. These costs may be substantial in antitrust cases, which are typically complex, and hence the costs of legal representation may generate substantial expenses. For example, in Germany — one of the most plaintiff-friendly jurisdictions - antitrust damages actions can generate significant costs to the other side. ${ }^{30}$ Another point

27 Communication op.cit note 9, at 7-8.

28 See, e.g. J.M. Landers, "Of Legalized Blackmail and Legalized Theft: Consumer Class Actions and the Substance-Procedure Dilemma", Southern California Law Review 47 (1974), $842-890$, at 843 .

29 Case C-199/o8 Erhard Eschig v.UNIQA Sachversicherung AG [2009] ECR 1-8295, para. 64.

30 Oberlandesgericht Düsseldorf (Higher District Court), judgment of 18 February 2015, VI-U (Kart) 3/14, NZKart 2015, 201. The Court calculated that if the defendant won the case, the other side's claim would generate more than $€_{5}$ million euros to the claimant. 
is that investors should consider the fact that bringing antitrust claims will require extensive evidences, but the EU discovery is subject to many conditions and limitations. ${ }^{31}$ Furthermore, performing the proportionality test of disclosure is the responsibility of national courts, which are unpredictable in their execution. In addition, judges are responsible for the screening of whether collective actions pass the test of commonality and suitability. ${ }^{32}$ Under such circumstances, investors are mainly interested in taking meritorious cases, which will generate strong evidences for passing the certification and for proving damages. In contrast, speculative claims are weak in their nature, as they lack merit.

Punitive damages do not inherently lead to overcompensation of the claimant party. The European Commission does not specify how expensive antitrust collective actions can be. In reality, the litigation costs (administrative, expertise, etc.) can be so high that they consume a large portion of the recovery, thereby leaving small amounts to victims. ${ }^{33}$ Therefore, the award of punitive damages may be needed to counterbalance the enforcement costs of the compensation objective. But if the case generates overcompensation to claimants, the surplus can be distributed on a cy-pres basis, under which unclaimed funds are provided to non-profit beneficiaries. ${ }^{34}$ This compensation distribution model is well illustrated through the Rover case in the UK. ${ }^{35}$ The European Commission detected price fixing by Rover, who was required to pay £1 million in compensation to consumers. ${ }^{36}$ It proved impossible to define customers to

31 Directive, op.cit note 1, Article 5.

32 See, e.g. Ž. Juška "The Impact of Contingency Fees on Collective Antitrust Actions: Experiments from Lithuania and Poland", Review of Central and East European Law 41(3-4) (2016) 368-395, at 377-380 (tbl. 1).

33 For high expenses in opt-in cases, see UFC-Que Choisir "Consultation de la Commission Europenne sur les Recours Collectifs Contribution De L UFC-Choisir" (2011). For high expenses in opt-out cases, see D.A. Crane, "Optimizing Private Antitrust Enforcement", Vanderbilt Law Review 63 (2010), 675-723, at 682-83.

34 In favour of a cy-pres remedy is the UK consumer organization, see Which?, op.cit note 14. A cy pres remedy has been very popular in the us. However, it has been criticized for distributing a surplus to the beneficiaries who are not related with the violation. See, e.g. J. Johnston, "Comment, Cy Pres Comme Possible to Anything Is Possible: How Cy Pres Creates Improper Incentives in Class Action Settlements", The Journal of Law, Economics \& Policy 9 (2013) 277-304, at 292-93.

35 European Commission, "Commission Decision on Rover Case" Press Release, available at $<$ http://europa.eu/rapid/press-release_MEMO-9o-31_en.htm>.

36 A. Maciuleviciute, 'Litigation Funding in Relation to the Establishment of a European Mechanism of Collective Redress' (2012) BEUC position. Retrieved 22 April 2017, http:// www.beuc.org/publications/2012-00074-01-e.pdf. 
whom the antitrust violation caused harm. Therefore, Which? - the U K consumer organisation-received the majority of money to spend on information projects: one regarded informing people about car safety and another regarded informing about the accessibility of cars for disabled people. ${ }^{37}$

On the basis of these points, it can be argued that the Commission missed the opportunity to suggest a more assertive approach. An assertive mechanism should be understood as crossing the borders of the EU compensation-based model, which combines conservative tools. If there was flexibility in utilising one or more American elements, there would be more possibilities to seek a better means of compensation. However, the us system should not be understood as the best fit for the EU mechanism, as it differs greatly in terms of rationale, design, and stated goals. Instead, the Commission should take a closer look at member states, which do not fully rely on the proposals by the Recommendation, but where antitrust collective actions have been working in practice.

EU Member States' Experiments with Forceful Tools

So far, antitrust collective litigation has been viable in member states, where collective proceedings are based on an opt-out basis. There are three countries that require further discussion. Each of them will be discussed in turn.

\subsection{Portugal}

In Portugal, Law 83/95 of 31 August (1995) allows a 'popular action' to be brought (acção popular), which is equivalent to us-style class actions. ${ }^{38}$ The first opt-out antitrust damages claim was filed against Sport TV, which held

37 A. Maciuleviciute, 'Re-directing Justice' (2012) BEUC position. Retrieved 22 April 2017, http://www.beuc.eu/publications/2012-00561-01-e.pdf.

38 The legislator gave effect to article $5^{2}$ (3) of the Constitution of the Portuguese Republic in order to promote the protection of general interest, such consumer protection, health, antitrust and etc. There are three types of popular actions: popular action for compensating damages (including class actions), preventive popular actions and popular action to dispute administrative actions. For further discussion, see R.V. Reis and M. Mesquita, "Portugal" British Institute for International and Comparative Law, available at $<\mathrm{http}: / /$ www.collectiveredress.org/collective-redress/reports/portugal/overview $>$; H.S. Antunes, 'Class Actions, Group Litigation \& Other Forms of Collective Litigation (Portuguese Report)' (2007). Retrieved 22 April 2017, http://globalclassactions.stanford.edu/sites/de fault/files/documents/Portugal_National_Report.pdf. 
an illegal monopoly in paid premium sports channels. ${ }^{39}$ The action sought to compensate over 60o,00o customers for damages directly arising from the anticompetitive conduct, and to compensate 3,000,000 customers for damages indirectly occurring due to the inflation of prices and the reduction of competition. ${ }^{40}$ The events behind the case initiation were somewhat unique: the claim was filed by the Portuguese Competition Observatory, a non-profit association of academics from a number of universities. At first glance, it may show that collective actions can be brought on the sole basis of opt-out. However, it rather seems to be an incidental tentative action of academics who, due to their professional curiosity, decided to experiment with the first popular action in antitrust. It is hard to imagine that a second lawsuit will be brought on the same basis in the absence of private funding tools,attorney's contingency fees or the third party funding.

That this case is exceptional can be illustrated through the Danish example. It offers the possibility of an opt-out class action when claims are very small (not exceeding DKK 2000, which is around $€ 270$ ), but only if the consumer ombudsman acts as group representative. ${ }^{41}$ Since opt-out collective actions became available in 2008 , the measure has not been yet tested in the antitrust area.

\subsection{The Netherlands}

The Act on Collective Settlement of Mass Damage Claims (WCAM) allows for the Amsterdam Appeal Court to declare a binding collective settlement, unless someone declares to opt-out. ${ }^{42}$ Interestingly enough, collective settlements are different from collective actions. The WCAM is codified in sections 7:908-7:910 of the Dutch Civil Code and articles 1013-1018 of the Dutch Civil Procedure Code. Collective actions are governed by article 3:305a of the Civil Code. This provision allows for foundations or associations (not an individual claimant) to seek a declaratory relief, but the Code does not establish the possibility to bring a compensatory damages action. ${ }^{43}$ It is considered that a declaratory relief may incentivise the alleged infringer to enter into a settlement agreement

39 Lisbon Judicial Court, case no. 7074/15.8T8LSB.

40 M.S. Ferro, "Collective Redress: Will Portugal Show the Way?" Journal of Euro Competition Law \& Practice 6(5) (2015), 299-300, at 300.

41 The Danish Administration of Justice Act, cf. Consolidated Act No. 1261 of October 23, 2007 .

42 The Law of 23 June 2005, Stb. 340.

43 For discussion, see J.E. Richman, 'United States: Dutch Collective Actions vs. Collective Settlements' (2016), available at <http://www.mondaq.com/unitedstates/x/536358/ Shareholders/Dutch+Collective+Actions+vs+Collective+Settlements $>$. 
with victims for compensating damages under the WCAM. In addition to the availability of opt-out collective settlement, the Netherlands is exceptional for favourable rules on the 'loser pays' principle. ${ }^{44}$ It should be stressed that a new Dutch bill on collective damages action was presented to the Parliament in November 2016. It is unknown what the final form of the legislation will be, but an opt-out tool was proposed as a main tool under the preliminary document. ${ }^{45}$

So far, the most notable antitrust mass claim was instituted by Claims Funding International (Equilib) on behalf of victims across Europe against KLM, Air France and Martinair. ${ }^{46}$ In September 2010, Equilib filed a claim exceeding $€ 400$ million in relation to the Commission's decision in the air cargo cartel. ${ }^{47}$ Notably, the case was brought on behalf of direct purchasers and indirect purchasers (including Phillips and Ericsson). In January 2015, Equilib brought a claim against British Airways and Lufthansa on the same factual and legal basis as in the first case. ${ }^{48}$ So far, both cases have not attracted criticism regarding abusive litigation by Equilib.

\subsection{The United Kingdom}

Schedule 8 of the 2015 Consumer Rights Act contains amendments to the Competition Act 1998 so as to provide possibilities for opt-out collective proceedings in the context of competition law infringements. A new collective actions regime is only available in the Competition Appeal Tribunal (CAT). But opt-out collective actions can only bind claimants domiciled in the UK. Under the new possibility, two follow-on antitrust collective actions have been brought.

In May 2016, the first one was brought by Ms. Dorothy Gibson (the proposed class representative) against Pride Mobility Products (the proposed defendant). ${ }^{49}$ The proposed follow-on collective proceedings were based on

44 See, e.g. Frank van Alphen, 2010. "Luchtvrachtkartel Krijgt reuzeclaim van Verladers." De Volkskrant. September 30 (citing Pierre Bos, the former counsel in the case of Equilib vs. $K L M$, who claimed that the Dutch courts were chosen because of the favourable rules on the "loser pays" principle, as plaintiffs do not have to pay for the actual costs incurred by the defendants).

45 I. Tzankova, 'New Dutch Bill on Collective Damages Action' (2016)<http://conflictoflaws .net/2016/new-dutch-bill-on-collective-damages-action/> accessed 19 January 2017.

46 Claims Funding International plc. Press Release (30 September 2010).

47 Airfreight (Case сомP/39258) Commission Decision C(2010) 7694 [2010] OJ C 371.

48 See Amsterdam District Court, 7 January 2015 (c/13/561169 / HA ZA 14-283). In the decision, it was asserted that the District Court of Amsterdam has jurisdiction over antitrust follow-on claims instituted by Equilib against British Airways and Lufthansa.

49 Competition Appeal Tribunal, Notice of an Application to Commence Collective Proceedings under Section $47 \mathrm{~b}$ of the Competition Act 1998, Case No. 1257/7/7/16. Retrieved 
the decision of the Office of Fair Trading, finding that Pride Mobility Products violated competition law through a form of resale price maintenance between 2010 and 2012. ${ }^{50}$ Around 30,000 victims were included in the class under an opt-out basis, and they were alleging an overpayment for mobility scooters. Class members were entitled to compensation of around $£_{7.7}$ million, or around $£_{200}$ each. It remains unclear how this claim is going to be funded if the certification was granted. The 2015 Consumer Rights Act prohibits the use of contingency fee agreements in collective proceedings. Instead, NPC's class action has been brought using a combination of a conditional fee agreement and after-the-event (ATE) insurance. During the class certification hearing in December 2016, the CAT issued a decision that the proposed subclasses were not well associated. ${ }^{51}$ As a consequence, Gibson requested an adjournment to reformulate her claim. In March 2017, the CAT approved the request and has granted a second attempt to amend the lawsuit. ${ }^{52}$ At this point, it can be considered a success that Gibson was found to be a suitable class representative. Yet, the Tribunal has proved to be rigorous when evaluating common issues in class certification.

In September 2016, another collective action was brought by an English solicitor (Walter Merricks) in the case Merricks v. MasterCard. ${ }^{53}$ A damages claim was filed on behalf of British consumers (around 46 million) against MasterCard, which allegedly imposed illegal charges from 1992 to 2007. The claim is based on a finding made by the European Commission in 2007. ${ }^{54}$ The value of the claim is around $£_{14}$ billion, making it the largest legal claim in UK history.

22 April 2017, http://www.catribunal.org.uk/files/1257_Dorothy_Gibson_Summary_210616 .pdf (summary of the case).

50 Office of FairTrading, decision of 27 March 2014, CE /9578-12. Retrieved 22 April 2017, https:// www.gov.uk/cma-cases/investigation-into-agreements-in-the-mobility-aids-sector.

51 Competition Appeal Tribunal, Dorothy Gibson v Pride Mobility Products Limited, Case No. 1257/7/7/16. Retrieved 22 April 2017, http://www.catribunal.org.uk/237-9255/1257-7-7 -16-Dorothy-Gibson.html.

52 Competition Appeal Tribunal, Judgment (Application for a Collective Proceedings Order) of 31 March 2017. Retrieved 22 April 2017, http://www.catribunal.org.uk/files/1257_Doro thy_Gibson_Judgment_CPO_CAT_9_310317.pdf.

53 Competition Appeal Tribunal, Notice of an Application to Commence Collective Proceedings under Section $47 \mathrm{~b}$ of the Competition Act 1998, Case No. 1266/7/7/16. Retrieved 22 April 2017, http://www.catribunal.org.uk/files/1266_Walter_Hugh_Summary_210616 .pdf (summary of the case).

54 MasterCard/EuroCommerce/Commercial Cards (Case COMP/34.579—COMP/36.518 COMP/38.580) Commission Decision of 17 December 2007 [2009] OJ C 264/8. 
The litigation funder (the Chicago-based company Gerchen Keller Capital) will provide funding of up to $£ 40$ million to finance the lawsuit.

\subsection{Third Party Funding and Contingency Fees}

These cases show that mass claims (with the unique exception in Portugal) should be reinforced by third party funding and opt-out schemes. Another form of third party funding for financing antitrust collective claims has been the so-called Special Purpose Vehicle. Under this model, operations are limited to the purchase or the assignment of claims (varying from several to dozens), thereby taking the hassle of subsequent enforcement. As a consequence, the assignment of claims is limited to cases that individually generate significant damages, usually after the European Commission's DG Competition's decision in cartel cases. So far, the most prominent private litigator has been the Cartel Damage Claims SA (CDC), a company incorporated under Belgian law but with its main activities being performed in Germany. However, the future of the CDC (and other SPV) has become very unclear after the Düsseldorf District Court's decision. ${ }^{55}$ In that case, 36 damaged companies purchased the cartelrelated claim to the CDC. The Court dismissed the claim because the CDC was found to have insufficient funds to cover the other side's costs if the defendant won the case. ${ }^{56}$ This case shows how the 'loser pays' principle can act as an effective deterrent against abusive litigation, but it also can serve as a device for significantly reducing the investor's possibilities to bring damages claims. However, some countries (as for example mentioned in the Netherlands) have more lenient rules on the 'loser pays' principle. Therefore, the magnitude of deterrence depends on a country-by-country basis.

The major problem is that third party funding is quite unpopular or unavailable in EU states, except for the ones mentioned before. Another funding option for collective actions is contingency fee agreements, where fees (a percentage of the class recovery) are paid only if the case was won. However, contingency fees are prohibited in most states; legal standing is typically limited to public authorities. ${ }^{57}$ Few countries allow contingency fee agreements in the event of collective actions, but these agreements have not been utilised in case of

55 Oberlandesgericht Düsseldorf op.cit note 25 .

56 In case of the ultimate loss, the other side costs for CDC would be around 5 million euros. Therefore, the Court concluded CDC is financially incapable of leading the case.

57 See, e.g. M.G. Warren III, "The U.s. Securities Fraud Class Action: An Unlikely Export to the European Union" Brooklyn Journal of International Law 37(3) (2012) 1075-1114, at 1089. According to the author, the standing is established for governmental authorities 
antitrust collective litigation. ${ }^{58}$ Another option is conditional fee agreements, under which attorneys/litigators receive an hourly fee, but a success fee is also paid if the case won. However, this funding option is highly restricted in collective actions, because claimants are still required to pay hourly legal fees for attorneys, which may be substantial.

\section{Litigation Abuses: A Perspective on the Us and the EU}

The experiences and initiatives discussed above show that combining thirdparty litigation and opt-out schemes does not attract the perceived issue of "blackmail settlement". This is not surprising, given that the occurrence of this phenomenon in the EU context is highly unlikely. Even if contingency fees (accused of attracting "fishing expedition"59) were combined with opt-out schemes, there is a low likelihood of plaintiffs being able to compel businesses to settle cases lacking merit. Still, there would be significant differences in the antitrust systems of the US and the EU, which are illustrated in Table 2.

TABLE 2 A comparative analysis between the US and the $E U$

\begin{tabular}{|c|c|c|}
\hline Measure & $\begin{array}{l}\text { United States } \\
\text { (deterrence-oriented) }\end{array}$ & $\begin{array}{l}\text { European Union } \\
\text { (compensation-oriented) }\end{array}$ \\
\hline Damages award & $\begin{array}{l}\text { Permits an award of treble } \\
\text { damages }\end{array}$ & $\begin{array}{l}\text { Allows the award of full } \\
\text { compensation, which prevents } \\
\text { the overcompensation of } \\
\text { claimants }\end{array}$ \\
\hline Discovery & $\begin{array}{l}\text { Liberal party-initiated } \\
\text { discovery }\end{array}$ & $\begin{array}{l}\text { The discovery is only possible } \\
\text { when the court approves the } \\
\text { proportionality of the request }\end{array}$ \\
\hline Cost allocation method & One-way-fee shifting rule & "Loser pays" principle \\
\hline Final outcome & Jury trials & Court decision \\
\hline
\end{tabular}

(e.g. Finland), consumer associations (e.g. Greece, France) and to other specified organizations (e.g. Portugal).

$5^{8}$ Contingency fees are allowed in collective actions in Germany, Lithuania, Poland, Spain, and Sweden. However, there have been no antitrust collective actions on the basis of a contingency fee agreement.

59 Communication op.cit note 9, at 8. 
It can be seen that deterrence-based measures are particularly unique for the us mechanism. In the first place, federal antitrust laws allow automatic awards of treble damages to plaintiffs. ${ }^{60}$ Indeed, this measure can expose the defendant to significant potential costs. ${ }^{61}$ To the same extent, the liberal party-initiated discovery permits plaintiffs to propound broad discovery requests that entail substantial expenses. ${ }^{62}$ Another unique measure is that the us antitrust law is based on the one-way fee shifting rule, according to which plaintiffs are entitled to attorney's fees, but this provision does not apply to defendants. ${ }^{63}$ Finally, antitrust class actions should end in jury trials, thereby conferring a component of "unpredictability." ${ }^{4}$ When also combined with opt-out and contingency fees, plaintiffs are empowered (in cases with favourable conditions) to force defendants to even settle cases lacking merit.

In the EU context, the American measures listed in Table 2 are contrary (to a greater or lesser degree) to the legal traditions of civil law countries. As regards trebling of damages, it may lead to the unjust enrichment of claimants. Broad discovery rules may jeopardise the effectiveness of the leniency system. The "loser pays" principle is one of the central safeguards against abusive litigation in collective actions. Finally, jury trials are predominantly utilised in common law legal systems. It is therefore highly questionable whether blackmailing would be possible in the absence of the American elements listed in Table 2. It is true that opt-out schemes generate high aggregate value, but this is the only component that may potentially incentivize defendants to settle unmeritorious cases. However, opt-out schemes are not the main concern in the us. The major issue is the wide pre-discovery rules, which may generate massive costs for defendants. Also, there is a high risk of an unsuccessful outcome, because jury members are likely to view the defendant (usually a large corporation) from the negatively, regardless of if it abides by the law or not. When this risk is combined with the possibility of trebling of damages, defendants are incentivised to settle the case rather than risking going to final proceedings. In fact, these components are not possible in the $\mathrm{EU}$.

\footnotetext{
$60 \quad$ Clayton Act, 15 U.s.c. $\$ \S 15(a)$.

61 J.P. Davis and R.H. Lande, "Defying Conventional Wisdom: The Case for Private Antitrust Enforcement” Georgia Law Review 48 (2013) 1-81, at 37-39.

62 See, e.g. Boeynaems v. LA Fitness International, LLC 285 F.R.D. 331, 334-35, 341 (E.D. Pa. 2012).

63 Clayton Act, 15 U.s.c. $\S \S 15(a)$.

64 A. Jones, "Private Enforcement of EU Competition Law: A Comparison with, and Lessons from, the Us" in M. Bergström, M. Iacovides and M. Strand (eds.), Harmonising EU Competition Litigation: The New Directive and Beyond (Portland: Hart Publishing, 2016) p. 20.
} 
However, when opt-out schemes are combined with contingency fees, the possibility remains that litigation abuses will appear in different forms. Given the large financial interests at stake, group representatives (the lead plaintiff and the group advocate) may represent the group members inadequately in order to maximise their own benefits. The first possibility is that they will set disproportionately high contingency fees. The second is that group members will not be properly informed about their rights to leave the group. The third option is that group representatives will make early settlements with defendants, generating low awards. The fourth is that the undistributed awards of the group would be distributed in an abusive way. ${ }^{65}$ When compared to the "blackmail settlement", these abuses are more realistic in the EU context. Indeed, victims with small claims are not well aware of the case or its foundations. Typically, the group members give complete freedom to the group representatives, who can structure the case for their own benefit.

Then again, two factors may significantly reduce the incentives for wrongdoers to abuse the litigation. One factor is that the "loser pays" principle is reinforced by the lawyer's disciplinary liability rules in the national context. For example, an attorney can be removed from the Bar if he or she acts contrary to professional conduct. ${ }^{66}$ Another factor is that courts are closely involved in the proceedings, especially in the discovery, thereby allowing for the judge to decide whether disclosure requests are proportional or not. ${ }^{67}$ It also requires closer monitoring of group interests, especially in the certification stage. But, after all, determining the potential of abusive litigation is very complicated, because contingency fees have not been tested in opt-out schemes in the EU landscape. Nevertheless, it is clear that the phenomenon of abusive litigation may occur in different forms in the EU member states: first, each jurisdiction has introduced collective redress schemes in its own fashion; second, different safeguards have been introduced in order to prevent litigation abuses. To sum up, when shaping the future of collective litigation, EU legislators should pay particular attention to the member states' schemes (even if they differ to some extent) rather than relying on the us system, which is different in its stated objectives and legal traditions. Then again, the introduction of certain American elements does not necessarily lead to the perceived American problems, as proved by experiences in the EU states.

Hopefully, 2017, or 2018 at the latest will be when the European Commission takes positive actions in this policy area. Given states' uncoordinated

65 Juška, op.cit note $32,390$.

66 For the discussion on disciplinary penalties in Lithuania and Poland, see ibid., at 391-391.

67 Directive, op.cit note 1, Article 5 . 
initiatives, it is probably unrealistic that the European Commission will adopt a Directive for antitrust collective redress. It would be regarded a huge victory if the EU issued a sector-specific recommendation on antitrust collective actions, but this time including provisions (in some fashion) on opt-out schemes, contingency fees and third party funding. Indeed, in 2017 or 2018 the European Commission should give its final decision on whether collective redress actions will be regulated at the Eu level or not. Later it might be too late, as national schemes will deviate too far from each other. Therefore, creating an EU-wide antitrust collective litigation will become difficult, if not an impossible task.

\section{6}

\section{Conclusion}

The adoption of the Directive on damages actions has been a significant step toward achieving better means for victims to claim damages for breaches of antitrust law. However, the right to seek damages is significantly restrained for consumers with small claims; no action of this type could function without assertive schemes for aggregating claims. The Recommendation on collective redress is not very helpful for two reasons; first, it is not a legally binding document; second, the proposed measures suggest too many obstacles for compensatory collective actions to ever be brought. For both reasons, the Recommendation has failed to incentivise member states to adopt or amend the existing collective redress schemes on the basis of the proposed principles. Contrary to the current stance in the EU policy, some member states have experimented with American-style tools. Even if the national experiments have not triggered a flood of litigation, an increase in antitrust collective litigation can be found in Portugal, the Netherlands, and the UK. These states clearly demonstrate that an opt-out measure is the key element in ensuring compensation in antitrust mass actions, yet it still has to be reinforced by additional incentives to sue, like third party funding. Therefore, these pro-active states send a clear message to the EU legislators: compensatory collective actions are possible in the EU context, but only if there is possibility in utilising one or another American element.

In addition, it was found that the American issue of "blackmail settlement" is highly unlikely in the EU context, even if contingency fees and optout schemes were combined. But the EU should be aware of other types of litigation abuses. One of the main possibilities is that group representatives will represent group members inadequately. It means that they can structure the case in a way that they will obtain disproportionally high compensation at the expense of group members. Even though this behaviour is realistic, the 
possibility is significantly diminished due to available safeguards (such as, the "loser pays" principle and national ethics rules). In any case, no one can ensure that litigation abuses would not appear in some fashion in the EU states. Nevertheless, it is preferable to have effective collective redress schemes with a minimal possibility of abusive litigation than to have schemes without a future, as it is foreseen under the proposed principles of the Recommendation on collective redress.

To sum up, the success of EU compensatory collective actions is dependent on the American style measures. 2017 or 2018 at the latest is the time when the $\mathrm{EU}$ needs to decide whether collective redress should be regulated at the EU level; later it will be too late. If the positive decision is taken, the suggestion would be to rely on the schemes of member states and hence to allow some flexibility in using US-style remedies. But the mechanism on the basis of purely conservative tools should be denied, as it will have little or no impact on compensating victims with small harms. 